\title{
Observations of root growth of young poplar and willow planting types
}

Chris J Phillips ${ }^{1 *}$, Michael Marden $^{2}$ and Lambie M Suzanne ${ }^{3}$

\begin{abstract}
Background: Poplars and willows are used widely in soil conservation in New Zealand to prevent shallow landslides on hill country. Determining when plants become effective at soil stabilisation is important for developing guidelines and policy for land management. The aim of this study was to determine if the size of plant material (0.5-m stakes, 1-m wands, 3-m poles) influences the early below-ground plant growth of poplars and willows used in conservation plantings.

Methods: In a small field trial, the above- and below-ground growth of three forms of vegetative planting material (poles, wands, stakes) of two clones of poplar (Populus spp.) and willow (Salix spp.) were determined 9 months after planting. Whole trees were excavated and destructively sampled.

Results: Plant growth was rapid and exceeded previously reported New Zealand rates. Willows performed better than poplars in above-ground growth metrics (net tree height, above-ground biomass) and 3-m poles performed the best of the planting types tested (net tree height, above-ground biomass, below-ground biomass, total root length). Lateral roots grew more than $2.5 \mathrm{~m}$ and up to $5.5 \mathrm{~m}$ from the stem in 9 months.

Conclusion: While poles significantly out-performed smaller plant materials in most growth metrics and will continue to be the material of choice in most soil conservation applications, the growth of lesser-grade materials was still rapid and suggests that "lesser" grade materials could be used for erosion control especially where stock are excluded from planted areas. Root observations such as those from this trial, contribute to improving the understanding of how and when, and at what planting density, plants used in soil conservation become effective for controlling shallow landslide erosion in New Zealand.
\end{abstract}

Keywords: Above-ground biomass; Below-ground biomass; Populus sp; Salix sp; Shallow landslide erosion; Soil conservation

\section{Background}

New Zealand is inherently an erosion-prone country due to its geologic-tectonic setting, its location surrounded by oceans that give rise to often unpredictable and stormy weather, and its hilly and mountainous topography (e.g. McCaskill 1973). Extensive removal of indigenous vegetation occurred in the 19th and early 20th centuries as part of colonial development with the result that accelerated erosion occurred in many regions (e.g. Gage and Black 1979; DeRose et al. 1993). New Zealand's hilly landscapes not located in mountainous national parks are mostly managed for productive uses

\footnotetext{
* Correspondence: phillipsc@landcareresearch.co.nz

'Landcare Research, PO Box 40, Lincoln 7640, New Zealand

Full list of author information is available at the end of the article
}

that include pastoral farming and plantation forestry. This "hill country" incorporates land steeper than $12^{\circ}$ and comprises $69 \%$ of the country. Erosion ${ }^{\mathrm{a}}$ is a significant issue for much of this productive hill country and results in both on-site and off-site effects such as loss of pasture productivity (Lambert et al. 1984; Rosser and Ross 2011) and declining water quality in rivers (Davies-Colley et al. 2011). The direct costs of erosion are estimated to be in excess of NZ\$200 million per year, with many other indirect costs not being assessed (e.g. Krausse et al. 2001). However, in many areas, soil conservation practices and reforestation with exotic conifers have enabled productive uses to continue. Erosion has been mitigated for the most part, except in the largest or the most extreme rain events (e.g. Hicks 1991;

\section{Springer}

(c) 2014 Phillips et al.; licensee Springer; licensee Springer. This is an Open Access article distributed under the terms of the Creative Commons Attribution License (http://creativecommons.org/licenses/by/2.0), which permits unrestricted use, distribution, and reproduction in any medium, provided the original work is properly credited. 
Glade 2003). While woody vegetation (trees) has been shown to reduce erosion in many situations (e.g. Phillips et al. 1991; Marden et al. 1992; Zhang et al. 1993; Watson et al. 1999; Phillips and Marden 2005; Marden 2012), it may not be effective in treating the largest active gully systems (Marden et al. 2005a, 2011; Herzig et al. 2011). Vegetation is particularly suited to reducing shallow landslides and this has been demonstrated in a number of situations (e.g. Marden and Rowan 1993; Douglas et al. 2011).

The most common soil conservation practice in New Zealand uses introduced species of Populus (poplar) and Salix (willow) often planted as single trees or wide-spaced groups of trees (e.g. van Kraayenoord and Hathaway 1986; Douglas et al. 2009, 2010). These species have long been recognised for their ability to provide a soil-conservation benefit in New Zealand (Hawley and Dymond 1988; Hicks 1992; Thompson and Luckman 1993; Wilkinson 1999; McIvor et al. 2011).

Advantages of poplar and willow for soil conservation on unstable hill country include rapid establishment from stem cuttings, ease of establishment in the presence of grazing livestock (sheep/cows/deer), extensive lateral root development, high evapotranspiration rates during the growing season, and tolerance of seasonally wet soils (Wilkinson 1999). Plants are mainly established from 3-m-long unrooted stem cuttings (poles). Occasionally where livestock are not present, smaller diameter and shorter length materials (stakes or wands) are used (National Poplar and Willow Users Group (2007)).

Historical work on root systems of poplar and willow in New Zealand is limited to a handful of published studies (Hathaway 1973; Hathaway and Penny 1975) and unpublished reports (M. Vine $1980^{\mathrm{b}}$ ). Most of these have been carried out at Ballantrae Research Station or in localities near Palmerston North (Figure 1). More recent assessments of poplar and willow roots in New Zealand have used whole-tree excavation (e.g. McIvor et al. 2009), trenching (e.g. Douglas et al. 2010), and coring (McIvor et al. 2011) methods. These studies, while limited in species and/or clones, soil type, planting density, and numbers of trees extracted, have demonstrated the general root growth rates of poplars and willows on hill country (e.g. McIvor et al. 2005, 2008, 2009; Douglas et al. 2010). However, McIvor et al. (2011) noted the lack of quantitative data on the effectiveness of spaced Populus spp. and Salix spp. trees with diameter at breast height $(\mathrm{DBH})<300 \mathrm{~mm}$. As a consequence of limited data, particularly for young trees, recommendations for appropriate species and clones used to control erosion on specific sites have been based almost entirely on survival, above-ground characteristics, and practitioner experience (McIvor et al. 2011). Studies of the use of willows for bioenergy and for fodder (Kemp et al. 2001;

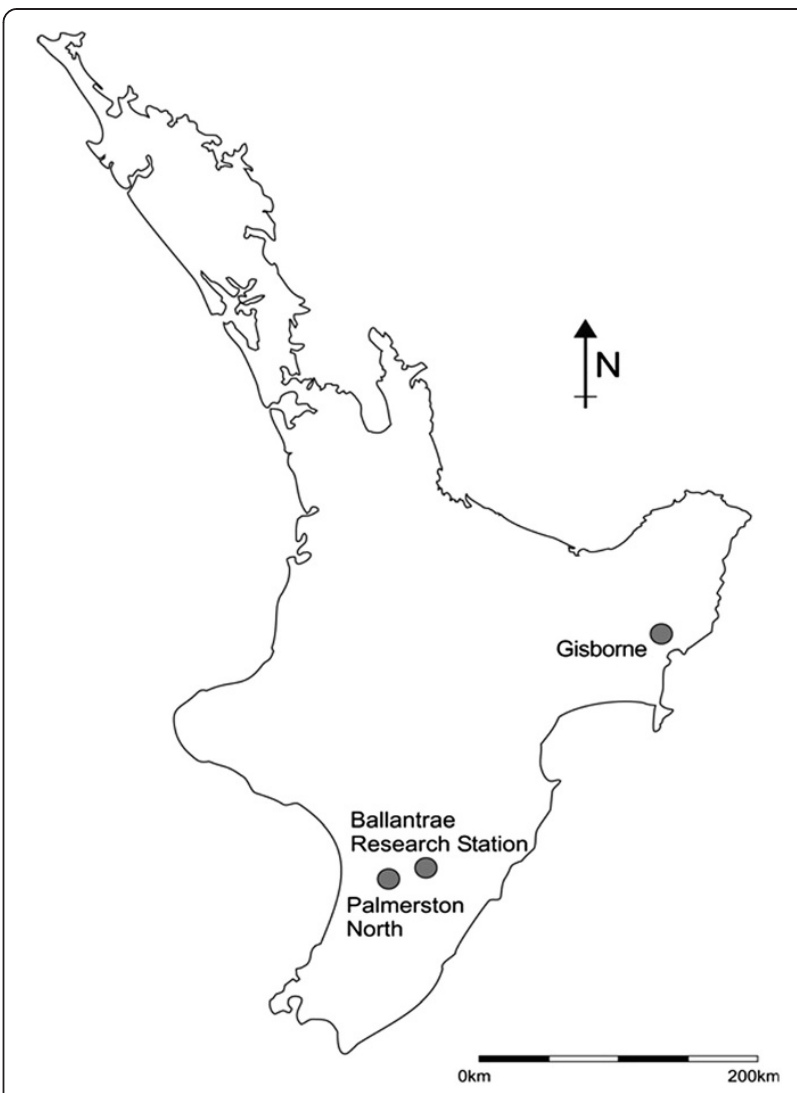

Figure 1 Map of the North Island of New Zealand showing Gisborne trial site and location of earlier studies on the roots of poplar and/or willow.

Sulaiman 2006) have demonstrated rapid above-ground growth rates, but contain limited below-ground data. The latter study also investigated a range of planting types (diameters from 10 to $35 \mathrm{~mm}$ and a cutting length of $600 \mathrm{~mm})$.

In 2006, a workshop was convened in Gisborne by the East Coast Forestry Project (ECFP) (O'Loughlin et al. 2008) with the aim to develop written guidelines outlining specifications for the treatment of eroding areas where poplar/willow pole planting could result in a successful erosion control outcome. Subsequent to that workshop, a need was identified to investigate the performance and effectiveness of erosion control treatments, including recommendations to assess the performance of willows and poplars grown from different types of vegetative material, including traditional 3-m poles, and smaller grade vegetative material such as cuttings, wands and stakes. Terms describing unrooted stem cuttings of poplar and willow have varied over time and across New Zealand. They relate to both length and diameter of the cutting (e.g. Van Kraayenoord et al. 1995, Wilkinson 1999). The terminology used by Gisborne District Council (Laura Savage pers. comm.) of pole $(3 \mathrm{~m})$, wand $(1 \mathrm{~m})$ and stake $(0.5 \mathrm{~m})$ has been adopted 
in this paper. However, currently, stake and wand are often used interchangeably in other parts of New Zealand to describe the $1 \mathrm{~m}$ variant. The term "cutting" is used here to refer to vegetative material in general used for propagation.

To address a knowledge gap of the growth of young poplar and willow, a trial of three types of planting materials of two clones each of poplar and willow aimed to assess early above- and below-ground growth (after 1, 2 and 3 years) to test the hypothesis that larger-grade vegetative material will outperform smaller (often called "lesser grade") material (i.e. poles $>$ wands $>$ stakes). This paper reports results after 9 months only from that trial.

\section{Methods}

\section{Site and species}

Three replicates of three types of planting material (stakes $(0.5 \mathrm{~m})$, wands $(1 \mathrm{~m})$ and poles $(3 \mathrm{~m})$ of each of two poplar clones and two willow clones (Table 1) were established in a field trial near Gisborne (Figure 1) in 2009. A randomised block design was used with all treatments in each block. The clones were Populus deltoides $\times$ yunnanensis 'Kawa' and $P$. deltoides $\times$ nigra 'Veronese' Salix matsudana $\times$ alba 'Hiwinui' and $S$. matsudana $\times$ alba 'Tangoio', (Table 1). Plants were to be grown for 3 years (108 plants in total). This trial was part of a wider on-going assessment of the performance of poplars and willows carried out by the New Zealand Willow \& Poplar Research Trust (http://www.poplarandwillow.org.nz/pages/home/) to meet other needs identified in the 2006 workshop.

The Gisborne trial was established on a low-lying, even-surfaced alluvial terrace adjacent to the Taraheru River in Gisborne City at the site of earlier "plant growth performance" trials to allow comparisons between species and clones (e.g. Marden et al. 2005b). Temperatures over summer average $23^{\circ} \mathrm{C}$ and over winter average $12^{\circ} \mathrm{C}$ and mean annual rainfall is $1000 \mathrm{~mm}$. The site $(50 \mathrm{~m}$ by $50 \mathrm{~m}$ ) was tilled before planting, weed mat laid to reduce competition from weeds, and trickle irrigation installed (to provide water during summer dry periods). The soil is free-draining Te Hapara sandy loam, a Typic Sandy Brown soil (Hewitt 1998). The soil has no physical or chemical impediments to root development to about $1.2 \mathrm{~m}$ depth, other than a variable-depth water table that fluctuates between greater than $1.5 \mathrm{~m}$ depth to within about $0.2 \mathrm{~m}$ of the surface. The soil appeared to be relatively uniform across the site, with a sandy loamy texture and no distinct zonal structure in the upper parts reflecting a history of cultivation. The site thus represents an almost 'best case' scenario for examining root development.

Plants were established according to the trial design on a $5 \mathrm{~m}$ by $5 \mathrm{~m}$ grid. The bottom of each cutting was bevelled/cut to a point to facilitate planting (approximately $15 \mathrm{~cm}$ for poles, $7 \mathrm{~cm}$ for wands and $5 \mathrm{~cm}$ for stakes). Planting types were "planted" by pushing or ramming the pointed cutting into the soil (3-m poles to depth of $0.7 \mathrm{~m} ; 1-\mathrm{m}$ wands to $0.4 \mathrm{~m} ; 0.5-\mathrm{m}$ stakes to $0.3 \mathrm{~m})$. A "representative" of each planting type of each clone was selected and oven dried until no further loss in weight was detectable to determine an initial value for the above- and below-ground biomass of the planted materials. Biomass was apportioned according to the proportion of the cutting above- and below-ground of each planting type. Root collar diameter (ground line diameter) and DBH (diameter at breast height over bark - $1.4 \mathrm{~m}$ above ground) where applicable, were measured at time of planting.

\section{Extraction methods and measurements}

Early in 2010 less than 1 year after planting, it became apparent that tree growth was rapid and beyond what had been initially expected, based on reported observations from earlier trials. It also became clear that the trial objectives would have to be modified or abandoned because root systems of some adjacent plants were beginning to overlap and compete for space. The 36 trees tagged for removal after the first year were removed as planned. Plants were extracted in May 2010 after one growing season (9 months from establishment - hereafter referred to as Year 1). Three trees of each planting type and clone (34 in total as two trees did not survive) were cut at ground level and destructively sampled. Given the size of the trees, the resources available were insufficient to extract and process the root systems of all

Table 1 Details of the plant species and types of vegetative material trialled

\begin{tabular}{|c|c|c|c|c|c|c|c|c|c|c|}
\hline \multirow[t]{3}{*}{ Clone name } & \multirow[t]{3}{*}{ Species parentage } & \multicolumn{3}{|c|}{$\begin{array}{l}\text { Mean diameter at ground level at } \\
\text { time of planting }(\mathrm{mm})\end{array}$} & \multicolumn{6}{|c|}{$\begin{array}{l}\text { Initial biomass of a representative sample of each } \\
\text { planting material }(\mathrm{kg})\end{array}$} \\
\hline & & \multirow[t]{2}{*}{ Pole } & \multirow[t]{2}{*}{ Wand } & \multirow[t]{2}{*}{ Stake } & \multicolumn{2}{|l|}{ Pole } & \multicolumn{2}{|l|}{ Wand } & \multicolumn{2}{|l|}{ Stake } \\
\hline & & & & & AGB & BGB & AGB & BGB & AGB & BGB \\
\hline 'Kawa' & Populus deltoides $\times$ yunnanensis 'Kawa' & 52 & 27 & 24 & 1.358 & 0.412 & 0.109 & 0.073 & 0.029 & 0.043 \\
\hline Veronese' & Populus deltoides $\times$ P. nigra 'Veronese' & 56 & 22 & 17 & 1.566 & 0.477 & 0.059 & 0.039 & 0.019 & 0.029 \\
\hline 'Hiwinui' & Salix matsudana $\times$ alba 'Hiwinui' & 55 & 20 & 18 & 1.226 & 0.373 & 0.066 & 0.044 & 0.018 & 0.028 \\
\hline 'Tangoio' & Salix matsudana $\times$ alba 'Tangoio' & 55 & 25 & 23 & 1.286 & 0.391 & 0.082 & 0.055 & 0.028 & 0.043 \\
\hline
\end{tabular}

Initial oven-dry biomass above- (AGB) and below-ground (BGB) based on proportion of cutting above or below the ground surface at time of planting (belowground: $23 \%$ poles, $40 \%$ wands, $60 \%$ stakes). 
replicates. Consequently, only one of each planting type (Tree \#1 of the trial design) was excavated for belowground information. Above-ground information was collected for all 3 replicates (where they survived). At this point the original trial objectives were abandoned. However, one pole only of each clone was selected to grow on for a further 1 and 2 years. Information on these eight Year 2 and Year 3 trees is not reported here because the sample size per clone was insufficient to enable statistical comparisons with the Year 1 plants. All remaining trees in the trial were cut at ground level and the stumps poisoned.

Root system extraction and measurement methods followed well-established procedures (e.g. Watson et al. 1999; Czernin and Phillips 2005; Marden et al. 2005b). Root systems were extracted using an air spade (a high pressure device to remove soil from around the roots) and by hand. Once removed from the ground, the plants were destructively sampled to determine a number of parameters that can then be related to root collar diameter (ground line diameter) or DBH (diameter at breast height over bark - 1.4 $\mathrm{m}$ above ground). Some of these parameters such as root spread, root depth, and total root length, can be used to compare the performance of a species in terms of effectiveness for erosion control (Phillips et al. 2011; Stokes et al. 2009). Measured above-ground parameters were height, canopy spread (not reported), root collar diameter and DBH (where applicable). Aboveground biomass was measured by separating the branches from the stem. Foliage (leaves) was not present at the time of sampling, having fallen off in the autumn.

Below-ground growth measurements included maximum root depth and maximum root spread, hereafter referred to as root depth and root spread. Root spread was taken as the average of the maximum lateral root spread diameter measured in two directions (N-S and $\mathrm{E}-\mathrm{W})$. The root system of each plant was photographed before being partitioned into $0.5 \mathrm{~m}$ radial and depth segments (Czernin and Phillips 2005; Marden et al. 2005b). Belowground components were partitioned into root bole (stump), tap, lateral and sinker roots. Roots were further partitioned into diameter size classes $(<1 \mathrm{~mm}$ (fibrous), $1.0-2.0,2.1-5.0,5.1-10.0$ and 10.1-20.0 mm) (Watson and O'Loughlin 1990), and the total length of roots in each diameter size class (excluding fibrous roots) was measured (Phillips et al. 2011). All plant components, both aboveand below-ground, were oven-dried at $80^{\circ} \mathrm{C}$ until no further loss in weight was detectable (24 hours minimum). Detailed topological assessment of root architecture, branching, etc., was not carried out.

\section{Analysis methods}

Due to the limited sample sizes ( $\mathrm{n}=3$ or less), means and standard errors were calculated and displayed only where appropriate. Analysis of variance (ANOVA) in combination with Student-Newman Kuells analysis (underdtaken with GenStat software version 12; VSN International, UK) was used to determine differences among the planting materials (i.e. pole, wand or stake) and among the different clones. For above-ground measurements of tree height and biomass, all of the available replicates were used ( $\mathrm{n}=3$ for each planting material/ clone combination). Due to less replication in the below-ground traits, analyses were undertaken by grouping the data by planting material $(n=3)$ and assessing the influence of the clone cultivar. Further, the influence of plant material on below-ground characteristics was assessed following grouping of the data by clone cultivar $(n=4)$. Differences between cultivars grouped with respect to species (i.e. poplar and willow) were undertaken using an unpaired, two-tailed, t-test. Analyses were considered to be significant if $P<0.05$.

\section{Results}

The intention was to extract 36 plants in Year 1. However, two of the three 'Kawa' poplar stakes died before sampling took place. The remaining 34 plants were all healthy.

In above-ground performance, poles were significantly taller $(P=0.006)$ than wands and stakes, which were not different from each other (Tables 2 and 3). However, when assessing the net height of the new growth for each planting type (i.e. the height 9 months after establishment minus the initial height of the cutting above ground), stakes and wands had greater net new height growth $(P=0.034)$ than poles (Table 3$)$. When the data was assessed for each clone/planting material, there was no significant difference in tree height among the treatments (Table 3). Net new growth in the 'Kawa' poles was less $(P<0.043)$ than the remaining treatments (Figure 2, Table 3). There was no difference between the willows and poplars with respect to tree height, however there was greater $(P<0.046)$ net new growth in the willows than the poplars (Table 3). The willow 'Tangoio' poles produced the tallest trees (mean $6.13 \mathrm{~m}$ ). While mean tree heights for 'Tangoio' wands and stakes were less than this (4.82 and $3.92 \mathrm{~m}$, respectively), the range among replicates for this clone suggests that growth performance was similar (wands 4.37-5.35 m, stakes 2.95$4.50 \mathrm{~m})$.

For both above- and below-ground biomass, poles outperformed $(P<0.001)$ wands and stakes irrespective of species (Table 3; Figure 3 ). Wands had more aboveground biomass than stakes $(P<0.001)$, but they were the same with respect to below-ground biomass (Tables 2 \& 3). For willows, a 'Hiwinui' pole produced the most above-ground biomass after 1 year with $16 \mathrm{~kg}$ (mean value of $14.5 \mathrm{~kg}$ above-ground) and $7 \mathrm{~kg}$ below ground. 
Table 2 Measurements of excavated poplars and willows after 1 year

\begin{tabular}{|c|c|c|c|c|c|c|c|c|c|c|}
\hline 1 & 2 & 3 & 4 & 5 & 6 & 7 & 8 & 9 & 10 & 11 \\
\hline Clone (planting type) & $\overline{\text { Height }(\mathrm{m})}$ & $\begin{array}{l}\text { Net new height } \\
\text { growth }(m)\end{array}$ & $\overline{\mathrm{DBH}}(\mathrm{mm})$ & $\begin{array}{l}\text { Root collar } \\
\text { diameter }(\mathrm{mm})\end{array}$ & $\begin{array}{l}\text { Total above-ground } \\
\text { biomass (AGB) (kg) }\end{array}$ & $\begin{array}{l}\text { AGB less } \\
\text { weight of initial } \\
\text { material }(\mathrm{kg})\end{array}$ & $\begin{array}{l}\text { Total below-ground } \\
\text { biomass (BGB) } \\
\text { (incl. stump) (kg) }\end{array}$ & $\begin{array}{l}\text { BGB less } \\
\text { weight of initial } \\
\text { material }(\mathrm{kg})\end{array}$ & $\begin{array}{l}\text { Root biomass } \\
\text { (excl. stump) } \\
\text { (kg) }\end{array}$ & $\begin{array}{l}\text { Total root } \\
\text { length }(\mathrm{m})\end{array}$ \\
\hline 'Kawa' (pole) & $3.97(0.94)$ & $1.68(0.95)$ & $55.3(4.4)$ & $73.0(10.6)$ & $3.78(1.79)$ & 2.42 & 4.56 & 4.15 & 3.35 & 379.04 \\
\hline 'Kawa' (wand) & $3.62(0.95)$ & $3.03(0.93)$ & $31.7(11.9)$ & $61.0(12.7)$ & $2.30(1.08)$ & 2.19 & 3.04 & 2.97 & 2.28 & 197.61 \\
\hline 'Kawa' (stake) & $4.75\left(^{*}\right)$ & $4.59(*)$ & $38.0(*)$ & $75(*)$ & $1.00(*)$ & 0.97 & 1.79 & 1.75 & 1.22 & 306.40 \\
\hline 'Veronese' (pole) & $5.71(0.16)$ & $3.75(0.15)$ & $72.7(4.1)$ & $104.0(1.5)$ & $7.57(0.44)$ & 6.00 & 4.58 & 4.10 & 3.05 & 254.65 \\
\hline 'Veronese' (wand) & $4.12(0.28)$ & $3.59(0.25)$ & $36.7(2.4)$ & $74.7(7.2)$ & $3.88(0.33)$ & 3.82 & 2.02 & 1.98 & 1.49 & 155.34 \\
\hline 'Veronese' (stake) & $3.99(0.11)$ & $3.86(0.10)$ & $34.7(0.3)$ & $77.3(8.3)$ & $2.35(0.20)$ & 2.33 & 1.89 & 1.86 & 1.50 & 224.80 \\
\hline 'Hiwinui' (pole) & $5.73(0.46)$ & $3.31(0.08)$ & $74.7(5.0)$ & $121.3(5.4)$ & $14.54(0.93)$ & 13.31 & 6.97 & 6.60 & 4.70 & 533.02 \\
\hline 'Hiwinui' (wand) & $5.41(0.21)$ & $4.66(0.03)$ & $48.3(2.0)$ & $86.3(1.8)$ & $5.60(0.36)$ & 5.53 & 3.16 & 3.12 & 2.30 & 483.98 \\
\hline 'Hiwinui' (stake) & $4.16(0.37)$ & $4.00(0.40)$ & 31.3 (3.8) & $79.0(3.2)$ & $3.18(0.52)$ & 3.16 & 2.96 & 2.93 & 2.2 & 219.09 \\
\hline 'Tangoio' (pole) & $6.13(0.35)$ & $3.95(0.31)$ & $76.5(1.5)$ & $109.0(2.1)$ & $9.93(0.58)$ & 8.64 & 7.79 & 7.40 & 5.52 & 525.33 \\
\hline 'Tangoio' (wand) & $4.82(0.29)$ & $4.27(0.28)$ & $34.7(5.5)$ & $95.7(3.2)$ & $5.34(0.74)$ & 5.26 & 4.13 & 4.08 & 3.30 & 280.71 \\
\hline 'Tangoio' (stake) & $3.92(0.49)$ & $3.78(0.49)$ & $30.3(4.7)$ & $90.0(6.4)$ & $3.32(0.33)$ & 3.29 & 2.47 & 2.43 & 1.72 & 287.04 \\
\hline
\end{tabular}

Above-ground data are from three trees per clone $(n=4)$ and planting type $(n=3)\left({ }^{*}=\right.$ dead tree). Below-ground data are from one tree per clone/planting type. Mean tree height (Column 2$)$, mean net new height growth is tree height less height of planting material above ground at time of planting (Column 3). Above- (Column 6) and below-ground (Column 8) biomass includes original material. Columns 7 and 9 are total less initial values listed in Table 1. Root biomass (excluding stump and initial value of planted material below ground) (Column 10). Total root length of all roots $>1 \mathrm{~mm}$ in diameter (Column 11). Figures in brackets are standard errors. 
Table 3 Mean tree height (Column 2), net new height growth (Column 3), above-ground biomass (AGB; Column 4), below-ground biomass (BGB; Column 5), root depth (Column 6), lateral root spread (Column 7) and total root length (Column 8) of willow and poplars grouped by clone, species or planting type

\begin{tabular}{|c|c|c|c|c|c|c|c|}
\hline 1 & 2 & 3 & 4 & 5 & 6 & 7 & 8 \\
\hline$\overline{\text { Clone/planting type }}$ & $\overline{\text { Height }(\mathrm{m})}$ & $\overline{\text { Net new height growth }(\mathrm{m})}$ & $\overline{\mathrm{AGB}(\mathrm{kg})}$ & $\overline{\mathrm{BGB}(\mathrm{kg})}$ & $\overline{\text { Root depth (m) }}$ & $\overline{\text { Root spread }(\mathrm{m})}$ & Root length (m) \\
\hline \multicolumn{8}{|l|}{ Clone } \\
\hline 'Kawa' & $3.93^{\mathrm{a}}(0.47)$ & $2.67^{\mathrm{a}}(0.65)$ & $3.0^{\mathrm{a}}(0.7)$ & $2.9^{\mathrm{a}}(0.6)$ & $0.6^{\mathrm{a}}(0.0)$ & $8.4^{\mathrm{ab}}(0.3)$ & $4.2^{\mathrm{ab}}(0.3)$ \\
\hline 'Veronese' & $4.61^{\mathrm{a}}(0.29)$ & $3.74^{\mathrm{a}}(0.10)$ & $4.6^{\mathrm{C}}(0.8)$ & $2.8^{\mathrm{a}}(0.5)$ & $1.0^{\mathrm{b}}(0.0)$ & $7.5^{\mathrm{a}}(0.8)$ & $2.1^{\mathrm{a}}(0.2)$ \\
\hline 'Hiwinui' & $5.10^{\mathrm{a}}(0.27)$ & $3.99^{\mathrm{a}}(0.23)$ & $7.8^{\mathrm{b}}(1.8)$ & $4.4^{\mathrm{a}}(0.8)$ & $0.6^{\mathrm{a}}(0.0)$ & $8.1^{\mathrm{ab}}(0.1)$ & $4.1^{b}(0.6)$ \\
\hline 'Tangoio' & $4.96^{\mathrm{a}}(0.37)$ & $4.00^{\mathrm{a}}(0.20)$ & $6.2^{d}(1.0)$ & $4.8^{\mathrm{a}}(0.9)$ & $0.5^{\mathrm{a}}(0.0)$ & $10.0^{\mathrm{b}}(0.3)$ & $3.6^{\mathrm{ab}}(0.5)$ \\
\hline$P$ value & 0.083 & 0.094 & $<0.001$ & 0.192 & $<0.001$ & 0.031 & 0.032 \\
\hline \multicolumn{8}{|l|}{ Species } \\
\hline Poplar & $4.31(0.28)$ & $3.27^{\mathrm{a}}(0.31)$ & $3.9^{\mathrm{a}}(0.6)$ & $2.9(0.6)$ & $0.8(0.1)$ & $8.0(0.7)$ & $2.5(0.3)$ \\
\hline Willow & $5.03(0.22)$ & $4.00^{\mathrm{b}}(0.15)$ & $7.0^{\mathrm{b}}(1.0)$ & $4.6(0.9)$ & $0.5(0.0)$ & $9.0(0.5)$ & $3.9(0.6)$ \\
\hline$P$ value & 0.054 & 0.046 & 0.014 & 0.151 & 0.059 & 0.246 & 0.065 \\
\hline \multicolumn{8}{|l|}{ Planting type } \\
\hline Pole & $5.39^{a}(0.33)$ & $3.17^{\mathrm{a}}(0.35)$ & $9.0^{\mathrm{a}}(1.3)$ & $6.0^{a}(0.5)$ & $0.6^{\mathrm{a}}(0.1)$ & $9.5^{\mathrm{a}}(0.4)$ & $4.2^{\mathrm{a}}(0.4)$ \\
\hline Wand & $4.49^{b}(0.30)$ & $3.89^{b}(0.29)$ & $4.3^{b}(0.5)$ & $3.1^{b}(0.2)$ & $0.7^{\mathrm{a}}(0.1)$ & $8.1^{\mathrm{a}}(0.6)$ & $2.8^{\mathrm{b}}(0.4)$ \\
\hline Stake & $4.09^{b}(0.16)$ & $3.95^{\mathrm{b}}(0.18)$ & $3.0^{c}(0.2)$ & $2.1^{b}(0.2)$ & $0.7^{\mathrm{a}}(0.1)$ & $8.0^{\mathrm{a}}(0.2)$ & $2.6^{b}(0.1)$ \\
\hline$P$ value & 0.006 & 0.034 & $<0.001$ & $<0.001$ & 0.660 & 0.063 & 0.014 \\
\hline
\end{tabular}

Values within clone, species or planting type with different letters were significantly different. $P$ values that were significant $(<0.05)$ are shown in bold. Figures in brackets are standard errors.

The mean above-ground biomass for 'Tangoio' poles was lower $(10 \mathrm{~kg})$ although the single pole extracted produced slightly more below-ground biomass $(7.8 \mathrm{~kg})$. The stumps or root boles contained between 20 and $30 \%$ of the below-ground biomass, with poles being in the upper end of this range compared with the other planting types. For poles, most of the root biomass was within $1.5 \mathrm{~m}$ of the stem ('Kawa' 83\%, 'Veronese' 75\%, 'Hiwinui' $78 \%$ and 'Tangoio' $79 \%$ ), even though roots extended beyond $5 \mathrm{~m}$ from the stem.

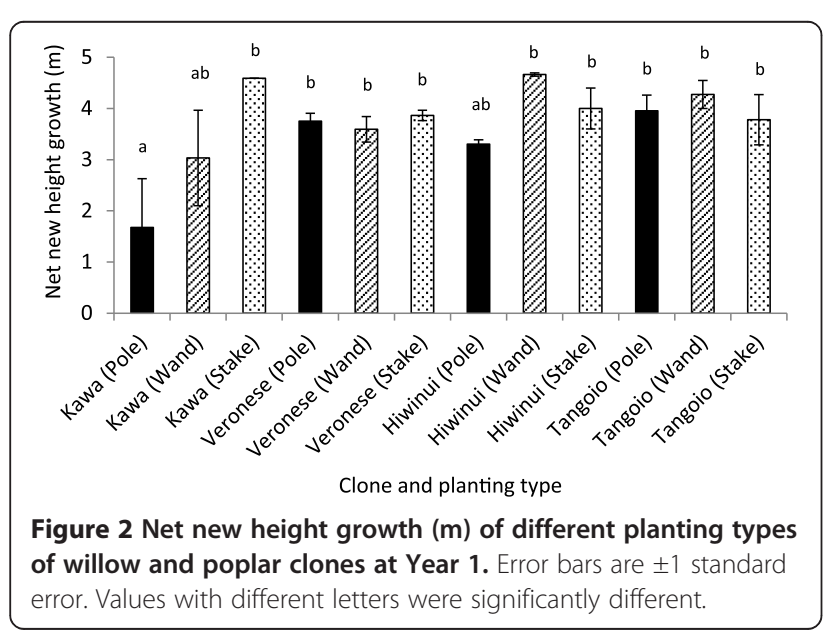

Differences among clones were observed in aboveground biomass only, whereby biomass was in the following order: 'Hiwinui'> 'Tangoio'>'Veronese'>'Kawa' $(P$ $<0.001$; Table 3). Thus the two willow clones outperformed the two poplar clones (Table 2).

Willow roots tended to be more numerous, finer and occupied more of the soil than poplar roots. The finer willow roots were more fibrous and "feathery" than those of poplars. Many of the fine willow roots arose off coarse "knobbly" laterals, whereas the poplars tended to

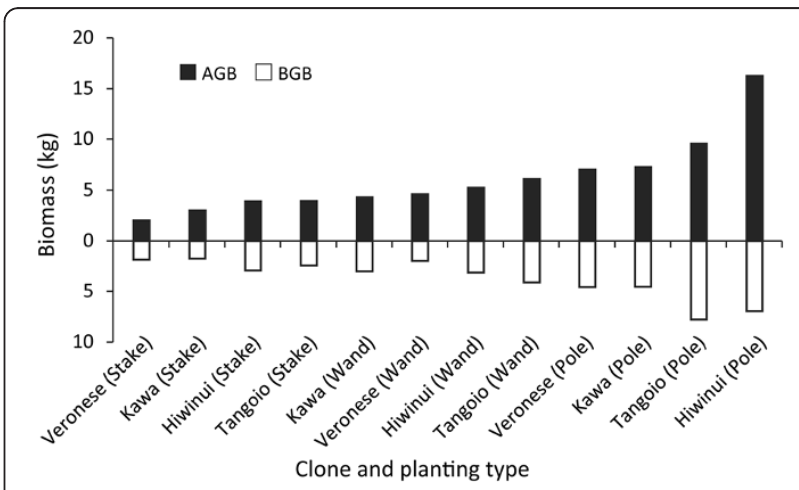

Figure 3 Above-ground biomass (AGB) and below-ground (BGB) biomass for willow and poplar planting types at Year 1 ( $n=1$ tree only, no means) arranged in order of increasing value from left to right. 
have longer, smoother, rope-like laterals. Year-1 poplar roots were finger-like in terms of thickness and showed little taper over much of their length once beyond a metre or so from the stem. This trait was present in willows but to a lesser degree. Poplar roots were bufforange in colour with 'Veronese' roots deeper in colour than those for 'Kawa'. 'Veronese' also had thin papery bark on the larger diameter lateral roots. When removed, a whiter-buff colour beneath was revealed. The bark surface also had many dark concentric discontinuous linear "stripes". Willow roots, in contrast, were more brown-tan in colour with 'Hiwinui' having more reddish tinges. All clones had long laterals that extended far from the stem, with poplars showing less branching than willows, i.e. having longer, single, unbranched roots.

All planting types exhibited generally spatially symmetric root distributions, with roots occupying all radial quadrants (data not shown). Between 30 and $50 \%$ of the total root length was within $1 \mathrm{~m}$ of the stem. The 1.0$2.0 \mathrm{~mm}$ and 2.1-5.0 $\mathrm{mm}$ root diameter classes combined accounted for about $75 \%$ or more of the total root length, with the finer category in some instances accounting for more than 60\%, though these roots make up only $20-40 \%$ of root biomass.

Unlike root length, below-ground biomass was concentrated closest to the stem for all planting types. Poles had more of their below-ground biomass closer to the stem than wands and stakes. This was because poles were initially of greater diameter and longer (i.e. more biomass belowground at planting) compared with the other planting types. Root biomass (total below-ground biomass less the stump) followed a similar pattern to root length, with biomass decreasing away from the stem. More than $90 \%$ of the root biomass was contained within half the distance of the maximum lateral extent ( $5 \mathrm{~m}$ ) and between 50 and $70 \%$ was within $1 \mathrm{~m}$ of the stem.

No consistent difference was observed among maximum root depths of planting types although analysis of data grouped by clone showed that the 'Veronese' trees all had greater $(P<0.001)$ rooting depth than the remaining clones (Figure 4; Table 3 ). All the planting types were installed from 0.30 to $0.70 \mathrm{~m}$ into the ground. Maximum root depth coincided either with sinker roots that emerged from lateral roots or from a series of smaller roots that emanated from the area immediately above the pointed tip of the planting material (the cambium layer under the outer bark). Many of these roots were about $2 \mathrm{~mm}$ (up to $10 \mathrm{~mm}$ ) in diameter, and were no more than about $200 \mathrm{~mm}$ in length. In contrast, sinker roots that developed from laterals were 10$20 \mathrm{~mm}$ in diameter, tapered along their length, reached depths of up to $1 \mathrm{~m}$, and often ended with splayed root tips. A sub-surface barrier, such as the seasonal water

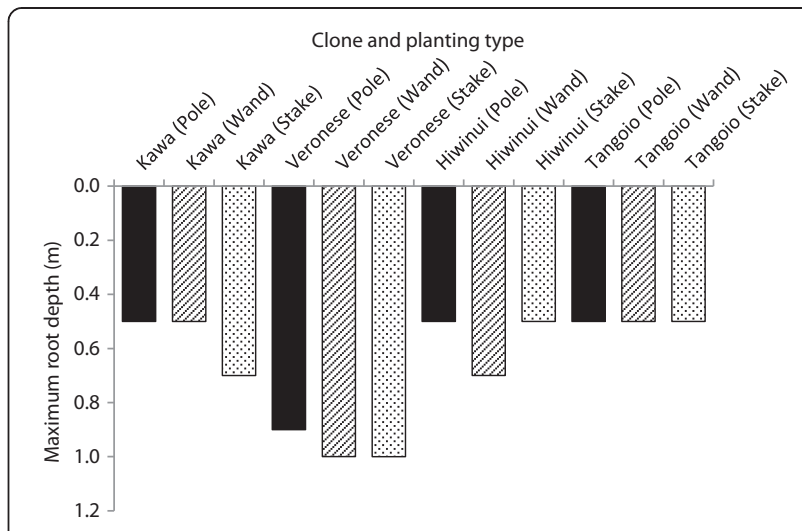

Figure 4 Maximum root depth for planting types of willow and poplar clones at Year 1.

table or a competent soil layer (such as pan) (or both), may have limited roots from going any deeper.

No significant differences were observed in root spread between willows and poplars or among planting types (Table 3 ). After one growing season (9 months), root spread of all planting types exceeded $5 \mathrm{~m}$. The 'Tangoio' pole had the largest root spread of $11 \mathrm{~m}$ (Figure 5).

The poles of each clone had the greatest $(P=0.014)$ total root length $>1 \mathrm{~mm}$ in diameter (Table 3; Figure 6), but the stakes and wands were not significantly different. There was no consistent pattern in total root length among the different clones, though the poplar stakes had greater total root lengths than the wands (Table 3).

Of the above and below-ground parameters assessed, only the above-ground biomass differed when data were grouped into willow and poplar categories, whereby there was considerably more $(P=0.014)$ above-ground biomass in the willow than the poplar trees (Table 3).

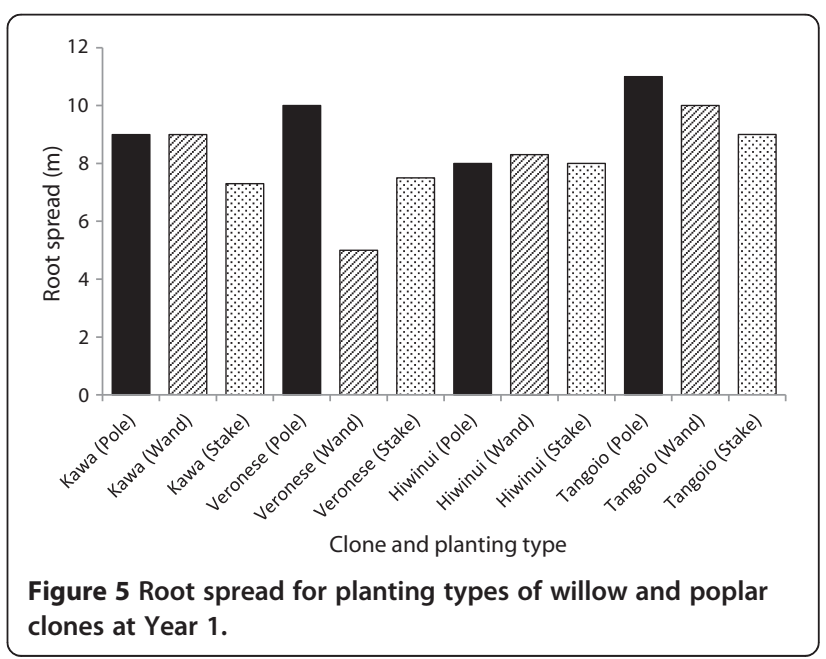




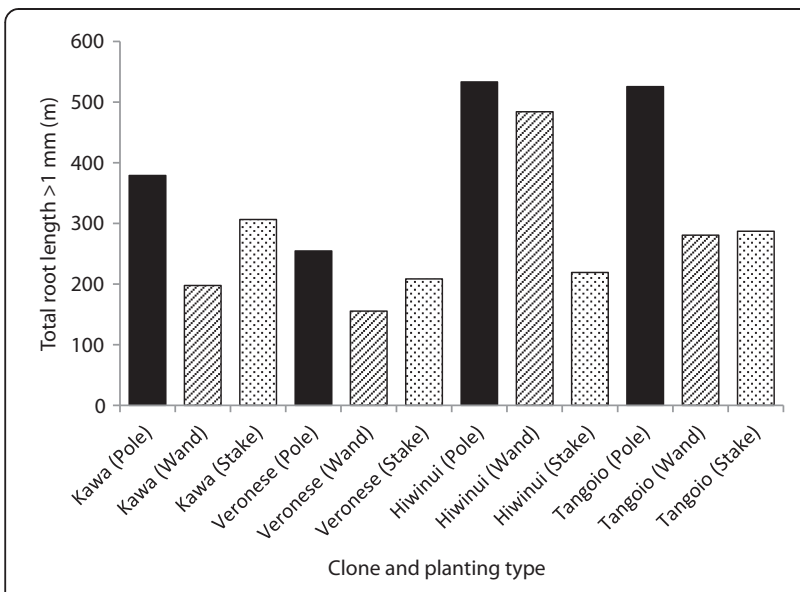

Figure 6 Total root length $>1 \mathrm{~mm}$ for planting types of willow and poplar clones at Year 1.

\section{Discussion}

There are limited studies that have investigated both the above-ground and below-ground early growth of poplars and willows, and fewer that have examined the influence of planting material size (stem length and/or stem diameter) on early growth and survival of clones of these two genera. In New Zealand, two studies are relevant. Vine $(1980)^{\mathrm{b}}$ examined the root development of 8 clones of poplar from 3-, 5- and 6-year-old trees growing on a fine sandy loam alluvial soil. Sulaiman (2006) examined the effect of $600-\mathrm{mm}$ stem cutting diameters and planting depths of clones of willow and poplar on tree establishment and biomass production from an alluvial, though finer grained more compact soil. Sulaiman (2006) found willow and poplar growth was more strongly influenced by stem diameter than planting depth (6 trees of each genus studied). Tree height and root numbers were greater in thicker than thinner willow stems, and mean root number was higher for willow than poplar. In general terms, this mirrors what was observed in the current trial with the larger diameter poles having greater total root length and biomass compared with smaller diameter planting types, and willows performing better across a range of metrics than poplars. However, it is not possible to directly compare data between the current study and Sulaiman (2006) because, in the latter study, the whole root system was not excavated and hence those reported root parameters are likely to be underestimates. Other New Zealand studies of poplar and willow were from older trees (e.g. McIvor et al. 2005, 2008, 2009; Douglas et al. 2010) and are thus not directly comparable.

A number of international studies of poplar and willow growth are reported in the literature (e.g. Fang et al. 2007; Čižkova et al. 2010). However, most are not directly comparable to this study being of too short a duration following planting (Branislav et al. 2009; Puri and Thompson 2003) or too long (Pacaldo et al. 2013), focused on assessing phytoremediation (Zalesny and Zalesny 2011) or usefulness for bioenergy production (Han et al. 2013), or not examining a similar set of metrics as the current study.

\section{Above-ground performance}

The rapid growth of trees observed in this study is likely to be due to the favourable growing conditions at the trial site. A relatively uniform sandy loam alluvial soil, warm temperatures, available moisture, and weed suppression, are all likely to have contributed to growth rates amongst the highest reported. Tree height or shoot length of 4-6 $\mathrm{m}$ in 9 months observed in this study exceeded the 3-4 m reported by Hathaway (1973) for 6 clones of willow and poplar after 1 growing season (11 months). Poplar shoot length (tree height) reported by Sulaiman (2006) ranged from $0.76-1.25 \mathrm{~m}$ after about 7 months (198 days) and willow shoot length ranged from 1.05-2.08 m. Tree heights for trees aged between 3 and 6 years reported by Vine $(1980)^{\mathrm{b}}$ ranged from $6.3-$ $11.0 \mathrm{~m}$. Sulaiman (2006) concluded that thick stems produced taller trees than thin stems.

International studies of poplar and willow plants established from cuttings to assess biomass for fuel potential indicate heights and aerial cover values similar to naturally established trees if the soil profile contains intermediate levels of fine textured soils and the maximum depth to groundwater is within $1.5 \mathrm{~m}$ of the ground surface (Caplan et al. 2012). Short rotation coppice willows and poplars are reported to grow best in loamy soils (Ledin and Willebrand 1996) where there is access to water (but not water logged). The growth of poplars was investigated as part of a trial by Hopmans et al. (1990) in Australia in which species were irrigated with municipal effluent. While root data were not recorded, tree heights of poplar clones after 1 year (interpolated from their Figure 1) ranged from $2.5-4 \mathrm{~m}$ and after 2 years were 3-7.5 m. Pallardy et al. (2003) recorded average tree height grown from $200 \mathrm{~mm}$ cuttings of 5 poplar clones growing on a silt loam after 1 year of $1.71 \mathrm{~m}$. This value nearly tripled after 2 years.

In summary, tree heights recorded in this study were at the upper end or exceeded those previously reported about $4 \mathrm{~m}$ after 1 year with maximum heights reaching nearly $6 \mathrm{~m}$.

Sulaiman (2006) reported total above-ground biomass for poplar from $0.112-0.743 \mathrm{~kg}$ after about 7 months (198 days) and willow from $0.064-0.508 \mathrm{~kg}$ all of which were substantially less than those recorded in this study, even with the original planting biomass removed (Table 2). Values from the literature for young willow and poplar often relate to very close spacings aimed at 
assessing bioenergy potential and are thus not directly comparable with results from this study.

\section{Below-ground performance}

Given the nature of the growing medium at the Gisborne site - a tilled sandy loam with few impediments such as rocks, stones or shallow compact layers (pans), it is not surprising that roots grew rapidly, but as mentioned earlier, growth rates were beyond that anticipated. Root growth observed in this trial exceeded those of any previously published information from similar trials or field situations in New Zealand and may also have exceeded those grown elsewhere, other than for young plants in experimental facilities such as rhizotrons (Lavaine pers. comm.), greenhouses (McIvor et al. 2013), or hydroponically (Zacchini et al. 2009).

Comparing data with other studies is difficult particularly for root length and root biomass as many studies do not fully excavate the root system, choosing instead to excavate a specified volume of soil around the stem that leaves a proportion of roots remaining in the soil. Further, in early New Zealand studies, information was collected only for root diameters $>2 \mathrm{~mm}$ or coarser or only partial excavations were carried out. In order to compare data from the current study with this earlier work, the finer root diameter class data had to be removed. These size classes also contain the largest proportion of total root length. It is also not possible to comment on clonal differences in relation to previous studies due to the lack of comparable data.

In a study of 5-year-old poplars from two sites, Hughes (unpublished report 1992, reported in McIvor et al. 2011), used intensive coring to a depth of $1 \mathrm{~m}$ to sample roots and found very few large woody roots > $2.5 \mathrm{~mm}$ in diameter at depth at the poorly-drained site compared to the well-drained site. Woody roots were found up to $4.3 \mathrm{~m}$ from trees in the poorly-drained site and up to $5.3 \mathrm{~m}$ from trees in the well-drained site. Similar root depths and radial root growth were observed in this study though occurring in less than 1 year.

McIvor et al. (2008) reported radial and vertical root growth of three 'Veronese' poplar trees of ages 5, 7, and 9.5 years growing on a hill-country New Zealand farm. Radial root growth was $8 \mathrm{~m}$ from the trunk for the 5 -yearold tree, $10-11 \mathrm{~m}$ for the 7-year-old tree, and $>14 \mathrm{~m}$ in the tree aged 9.5 years. In a similar study, McIvor et al. (2009) reported radial root growth of three 11.5-year-old trees that ranged from about $8 \mathrm{~m}$ to $12 \mathrm{~m}$ (interpolated from their Figure 1). The most comparable of the New Zealand studies is that of Vine $(1980)^{\mathrm{b}}$. Eight poplar clones of different species, planted at various spacings and from different planting types, were excavated by hand. Three 3-year-olds in a closely spaced stand, three 5-yearolds and two 6-year-olds at $6 \mathrm{m \times 1} 12 \mathrm{~m}$ spacing were assessed. A lateral root of a 3-year-old poplar in that study, reached up to $7.5 \mathrm{~m}$ from the stump and in this study, values of 3 to $5 \mathrm{~m}$ from the stem were reached in less than one-year indicating high lateral root growth rates. The 'Tangoio' pole measured in this study had the maximum root spread of $11 \mathrm{~m}$ after approximately 270 days after planting, equating to an average daily growth rate of about $20 \mathrm{~mm}$ per day. This is a similar order of magnitude to some crops such as wheat or maize (Watt et al. 2006) and to values recorded by Zacchini et al. (2009) for hydroponically grown poplars and willows after 3 weeks, but is generally high for woody species. For example, approximate daily root growth rates calculated using lateral root growth values published by McIvor et al. (2009) are an order of magnitude lower than recorded in this trial ( $3.4 \mathrm{~mm}$ compared with about $20 \mathrm{~mm}$ ). The daily rate is about $7 \mathrm{~mm}$ if the maximum lateral root value of Vine $(1980)^{\mathrm{b}}$ is used.

Vine $(1980)^{\mathrm{b}}$ also observed root systems were asymmetric, exhibiting strong growth into unplanted areas, and root grafting was observed between trees. There was considerable variation in vertical and lateral root growth between species, and among trees within clones.

In Vine's (1980) $)^{\mathrm{b}}$ study, roots were followed from the stump out to when the diameter reduced to $5 \mathrm{~mm}$. Fine roots were not examined because they were "too delicate to excavate without an inordinate amount of time being spent on them". Results indicated total root length $(>5 \mathrm{~mm}$ ) varied from 28 to $57 \mathrm{~m}$ for 3-year-old plants, 22-228 m for 5-year-old plants, and 136-153 m for 6year-old plants. The $1.0-2.0 \mathrm{~mm}$ and $2.1-5.0 \mathrm{~mm}$ root class values were removed from the total root length in the current study (6 poplar trees) in order to compare these data with the total root length data from Vine (1980) 'Kawa' total root length ( $>5 \mathrm{~mm}$ ) ranged from $42-55 \mathrm{~m}$, and 'Veronese' from 41-113 m. Both of these values are similar to those for the 3-year-old trees growing on a fine sandy loam alluvial terrace reported by Vine $(1980)^{\mathrm{b}}$. However, in this study these values were reached in less than 1 year, also indicating that root growth rates observed in the current study are high. Vine $(1980)^{\mathrm{b}}$ also observed that, within the first metre, roots showed strongly eccentric growth so that they were vertically thickened, and this effect was also observed in the current study. Total root length values of $2-4 \mathrm{~m}$ for poplar and 3-12 $\mathrm{m}$ for willow were reported by Sulaiman (2006) after 225 days (just over 7 months) and are considerably less than the several hundreds of metres recorded in the current study (Table 2). However, the values obtained by Sulaiman are likely to be less than the 'true' value as they came from only a limited volume of soil in which the tree was growing rather than from a full root system excavation.

Below-ground biomass and root biomass values obtained here also exceed those previously reported, though 
many earlier studies are not directly comparable. Root dry-matter production from Sulaiman's (2006) study ranged from about 1-67 g per tree for both willows and poplars, though the whole root system was not excavated. In comparison, values from the current study were $1-5 \mathrm{~kg}$ per tree (Table 2).

It is generally accepted that the morphology and distribution of roots are greatly affected by the immediate soil environment as well as by above-ground influences. In particular, soil type and soil density have a major influence on the development and distribution of adventitious roots within the soil profile (Davis et al. 1983; Sands and Bowen 1978). Also, the anchorage of Populus spp. grown from live poles depends on whether soil is frictional (sandy) or cohesive (clayey), with anchorage improved in the latter (Dupuy et al. 2007). The uniformly textured and fertile sandy loam at the Gisborne site provided ideal conditions for the development of an extensive lateral root network. The distribution of roots tended to be symmetrical as there were no other obvious soil constraints, particularly in the lateral direction. In contrast, denser, clay-rich, heterogeneous soils (such as those at the Palmerston North sites of earlier studies) may have restricted root growth and induced more asymmetric lateral root distributions (e.g. Vine $1980^{\mathrm{b}}$ ). Other soil constraints (perhaps more typical of earlier studies rather than the current trial site) include elevated soil moisture levels that limit root growth by hypoxia under wet conditions, presence of stones/boulders, and compact layers. Additional factors that are likely to contribute to differences in early growth performance among sites include the size/grade and condition of the planting material, the soil moisture levels and general climatic conditions at the time of planting, and planting aftercare.

Few international studies have assessed the effect of soil texture on lateral root development of poplars and willows. However, in studies that assessed above-ground performance as outlined above, short rotation coppice willows and poplars are reported to grow best in loamy soils (Ledin and Willebrand 1996) where there is access to water (but not water logged) - conditions similar to this trial. This was confirmed by Crow and Houston (2004) who found that the rooting habits of willow and poplar were influenced by many variables such as soil properties (physical, chemical, and hydrological), silviculture and species. In their study, poplars on well drained soils had more and deeper roots than on other soil types, but wetter soils produced shallower root systems.

In summary, root growth rates (root spread, root biomass, total root length) observed in the current study exceeded those previously reported in New Zealand and indicate what might be possible from sites with few impediments to root development, such as sandy-loam soils on alluvial terraces and with adequate soil moisture. The limited data from this study also support results from earlier studies that willow and poplar growth is strongly influenced by stem diameter with larger materials generally producing taller trees, with more roots (greater root number, root length, and root biomass).

\section{Conclusions and applications}

The observations from this trial expand the knowledge base of root growth of poplars and willows in New Zealand and fill an important gap in providing growth data in early years to assist in refining or confirming existing allometric models for these clones. Lateral root growth rates in this trial exceed those previously reported in New Zealand and indicate what might be possible from sites that have few impediments to root development. Information from these trials generally supports the findings of earlier work. However, growth rates significantly exceeded those earlier studies. It should be recognised that soil erosion plantings on hillslopes are likely to experience much different growing environments and are thus unlikely to grow at rates observed in this study.

Willows outperformed poplars for several of the metrics in question (above-ground biomass, below-ground biomass, total root length). These results indicate that, in the short term, they may be more effective in terms of soil reinforcement, at least under conditions similar to that of the trial site. However, on hill slopes and nonuniform soils, poplars may perform better than willows as their roots tend to be thicker allowing better penetration into more compact soils. Further, for the first year after planting, the larger diameter planting materials, such as poles, had better performance than lesser-grade materials, though these still performed well. Poles are preferred for soil-conservation applications, largely because they can withstand stock presence. However, lesser-grade materials, such as wands or stakes, could be used where cost is a concern. For example, poles typically cost between NZD\$15-20 per pole planted (\$6 ex nursery) with wands and stakes considerably less than this ( $\$ 1.20$ and $\$ 0.60$ respectively ex nursery).

Growth performance of plants can differ markedly depending on growth stage and physiographic site. The resulting data are thus less than ideal for developing reliable regression relationships between above- and belowground growth parameters. However, though founded on limited data, these relationships are critical for determining planting density requirements for situations where poplar and willow are the preferred means of soil conservation in New Zealand's erosion-prone hill country.

This trial, while providing more qualitative than detailed quantitative data, has provided additional information that 
adds to the general understanding of how these soil conservation plants perform under different site conditions. It has filled a gap in the current knowledge of the growth in the first year after planting, and has provided the first quantitative data on the growth of different vegetative materials. In terms of erosion control, the data largely support the view that larger vegetative materials at planting will perform better than lesser-grade materials. However, while lesser-grade wands and stakes did significantly lag poles in most growth metrics, growth was still rapid and root spread and root depth were not significantly different than poles. Thus, it might be reasonable to suggest that using smaller vegetative materials may be cost effective especially where stock are excluded from planted areas.

Finally, the paucity of below-ground tree-root data globally still limits the ability of practitioners to develop and refine predictive models for different species and/or clones and to refine or enhance recommendations on tree density and pattern to achieve erosion control. Observations of root growth presented here contribute to an improved understanding of how and when, and at what density, plantings become effective for controlling erosion.

\section{Endnotes}

${ }^{a}$ Erosion in this paper is defined as mass movement or shallow landslide erosion - landslides (soil slips), earthflows, debris avalanches, debris flows - and not specifically surface erosion.

bine, M, (1980). Root systems of some poplar trees. Unpublished report. National Plant materials centre, Palmerston North, New Zealand, 16 p.

\section{Acknowledgments \\ We acknowledge the support of the Tairawhiti Polytechnic Rural Studies Unit, on whose land the Gisborne plant trial was located. Peter Manson of Hawke's Bay Regional Council and Alan Hall of Gisborne District Council provided the plant material from council nurseries. Alex Watson and Alan Hughes assisted with the planting and Kaisa Valkonen, Sophie Michel, Ian Mclvor, and Nathan Arnold are thanked for assisting with excavations, processing and assembling data. Craig Ross reviewed an earlier draft and Christine Bezar edited the final version. Comments and suggestions from two unnamed reviewers and the Journal Editor significantly improved the final paper. The work was carried out as part of the Sustainable Land Use Research Initiative (SLURI) funded by the New Zealand Foundation for Research, Science and Technology (Contract C02X0813).}

\section{Author details}

${ }^{1}$ Landcare Research, PO Box 40, Lincoln 7640, New Zealand. ' Landcare Research, PO Box 445, Gisborne 4010, New Zealand. ' 2 andcare Research, Private Bag 3127, Hamilton 3240, New Zealand.

Received: 26 September 2013 Accepted: 3 June 2014

Published online: 07 August 2014

\section{References}

Branislav, K, Savo, R, Dragana, M, Petar, I, \& Marina, K. (2009). Early shoot and root growth dynamics as indicators for the survival of black poplar cuttings. New Forests, 38(2), 177-185.
Caplan, TR, Cothern, K, Landers, C, \& Hummel, OC. (2012). Growth response of coyote willow (Salix exigua) cuttings in relation to alluvial soil texture and water availability. Restoration Ecology, 21(5), 627-638.

Čižkova, L, Čižek, V, \& Bajajová, H. (2010). Growth of hybrid poplars in silviculture at the age of 6 years. Journal of Forest Science, 56(10), 451-460.

Crow, P, \& Houston, TJ. (2004). The influence of soil and coppice cycle on the rooting habit of short rotation poplar and willow coppice. Biomass \& Bioenergy, 26, 497-505.

Czernin, A, \& Phillips, CJ. (2005). Below-ground morphology of Cordyline australis (New Zealand cabbage tree) and its suitability for riverbank stabilisation. New Zealand Journal of Botany, 43, 851-864.

Davies-Colley, RJ, Smith, DG, Ward, RC, Bryers, GG, McBride, GB, Quinn, JM, \& Scarsbrook, MR. (2011). Twenty years of New Zealand's national rivers water quality network: benefits of careful design and consistent operation. JAWRA Journal of the American Water Resources Association, 47, 750-771.

Davis, GR, Neilsen, WA, \& McDavitt, JG. (1983). Root distribution of Pinus radiata related to soil characteristics in five Tasmanian soils. Australian Journal of Soil Research, 21, 165-171.

DeRose, RC, Trustrum, NA, \& Blaschke, PM. (1993). Post-deforestation soil loss from steepland hillslopes in Taranaki, New Zealand. Earth Surface Processes and Landforms, 18, 131-144.

Douglas, GB, Mclvor, IR, Manderson, AK, Todd, M, Braaksma, S, \& Gray, RAJ. (2009). Effectiveness of space planted trees for controlling soil slippage on pastoral hill country. In LD Currie \& CL Lindsay (Eds.), Nutrient management in a rapidly changing world (pp. 111-119). New Zealand: Occasional Report 22, Fertilizer and Lime Research Centre, Massey University, Palmerston North.

Douglas, GB, Mclvor, IR, Potter, FJ, \& Foote, LG. (2010). Root distribution of poplar at varying densities on pastoral hill country. Plant Soil, 333, 147-161. doi 10.1007/s11104-010-0331-4

Douglas, GB, Mclvor, IR, Manderson, AK, Koolaard, JP, Todd, M, Braaksma, S, \& Gray, RAJ. (2011). Reducing shallow landslide occurrence in pastoral hill country using wide spaced trees. Land Degradation \& Development, 24, $103-$ 114. doi: 10.1002/ldr.1106.

Dupuy, L, Fourcaud, T, Lac, P, \& Stokes, A. (2007). A generic 3D finite element model of tree anchorage integrating soil mechanics and real root system architecture. American Journal of Botany, 94, 1506-1514.

Fang, S, Xue, J, \& Tang, L. (2007). Biomass production and carbon sequestration potential in poplar plantations with different management patterns. Journal of Environmental Management, 85(3), 672-679.

Gage, M, \& Black, D. (1979). Slope-stability and geological investigations at Mangatu State Forest (New Zealand Forest Service Technical Paper 66). Wellington, New Zealand: New Zealand Forest Service.

Glade, T. (2003). Landslide occurrence as a response to dramatic land use change. Catena, 51, 297-314.

Han, SH, Shin, SJ, Kim, BR, Aggangan, NS, \& Yun, CW. (2013). Growth, chemical composition and energy contents of seven clones of one-year-old Salix caprea L. as short-rotation coppice. Asia Life Sciences, 22(2), 413-426.

Hathaway, RL. (1973). Factors affecting the soil binding capacity of the root systems of some Populus and Salix clones (MSc thesis). Palmerston North, New Zealand: Massey University.

Hathaway, RL, \& Penny, D. (1975). Root strength in some Populus and Salix clones. New Zealand Journal of Botany, 13, 333-344.

Hawley, JG, \& Dymond, JR. (1988). How much do trees reduce landsliding? Journal of Soil and Water Conservation, 43, 495-498.

Herzig, A, Dymond, JR, \& Marden, M. (2011). A gully-complex model for assessing gully stabilisation strategies. Geomorphology, 133, 23-33.

Hewitt, AE. (1998). New Zealand soil classification. Landcare Research Science Series 1 (2nd ed.). Lincoln, New Zealand: Manaaki Whenua Press.

Hicks, DL. (1991). Erosion under pasture, pine plantations, scrub and indigenous forest: a comparison from Cyclone Bola. New Zealand Forestry, 36(3), 21-22.

Hicks, DL. (1992). Impact of soil conservation on storm-damaged hill grazing lands in New Zealand. Australian Journal of Soil and Water Conservation, 5, 34-40.

Hopmans, P, Stewart, HTL, Flinn, DW, \& Hillman, TJ. (1990). Growth, biomass production and nutrient accumulation by seven tree species irrigated with municipal effluent at Wodonga, Australia. Forest Ecology and Management, 30, 203-211.

Kemp, PD, MacKay, AD, Matheson, AD, \& Timmins, ME. (2001). The forage value of poplars and willows. Proceedings of the New Zealand Grassland Association, 63, 115-119. 
Krausse, M, Eastwood, C, \& Alexander, RR. (2001). Muddied Waters: Estimating the National Economic Cost of Soil Erosion and Sedimentation in New Zealand. Lincoln, New Zealand: Landcare Research.

Lambert, MG, Trustrum, NA, \& Costall, DA. (1984). Effect of soil slip erosion on seasonally dry Wairarapa hill pastures. New Zealand Journal of Agricultural Research, 27, 57-64.

Ledin, S, \& Willebrand, E. (1996). Handbook on how to Grow Short Rotation Forests. Uppsala, Sweden: IEA Bioenergy, Department of Short Rotation Forestry, Swedish University of Agricultural Sciences.

Marden, M. (2012). Effectiveness of reforestation in erosion mitigation and implications for future sediment yields, East Coast catchments, New Zealand: a review. New Zealand Geographer, 68, 24-35.

Marden, M, \& Rowan, D. (1993). Protective value of vegetation on tertiary terrain before and during Cyclone Bola, East Coast, North Island, New Zealand. New Zealand Journal of Forestry Science, 23, 255-263.

Marden, M, Phillips, C, Jackson, R, Zhang, XB, \& Ekanayake, J. (1992). A Decade of Earthflow Research and Inter-Related Studies in the North Island of New Zealand. In DE Wallingford, TR Davies, \& B Hasholt (Eds.), Erosion, Debris Flows and Environment in Mountain Regions (p. 263). Wallingford, Oxfordshire: Publication 209, International Association of Hydrological Sciences.

Marden, M, Arnold, G, Gomez, B, \& Rowan, D. (2005a). Pre- and post-reforestation gully development in Mangatu Forest, East Coast, North Island, New Zealand. River Research and Applications, 21, 1-15.

Marden, M, Rowan, D, \& Phillips, C. (2005b). Stabilising characteristics of New Zealand indigenous riparian colonising plants. Plant Soil, 278, 95-105. doi: 10.1007/s11104-004-7598-2.

Marden, M, Herzig, A, \& Arnold, G. (2011). Gully degradation, stabilisation and effectiveness of reforestation in reducing gully-derived sediment, East Coast region, North Island. Journal of Hydrology (NZ), 50, 19-36.

McCaskill, LW. (1973). Hold this Land. A History of Soil Conservation in New Zealand. Wellington, New Zealand: AH \& AW Reed.

Mclvor, IR, Metral, B, \& Douglas, GB. (2005). Variation in root density of poplar trees at different plant densities. Proceedings of Agronomy Society of New Zealand, 35, 66-73.

Mclvor, IR, Douglas, GB, Hurst, SE, Hussain, Z, \& Foote, AG. (2008). Structural root growth of young Veronese poplars on erodible slopes in the southern North Island, New Zealand. Agroforestry Systems, 72, 75-86.

Mclvor, IR, Douglas, GB, \& Benavides, R. (2009). Coarse root growth of Veronese poplar trees varies with position on an erodible slope in New Zealand. Agroforestry Systems, 76, 251-264

Mclvor, IR, Douglas, G, Dymond, J, Eyles, GO, \& Marden, M. (2011). Pastoral Hill Slope Erosion in New Zealand and the Role of Poplar and Willow Trees in its Reduction. In D Godone \& S Stanchi (Eds.), Soil Erosion Issues in Agriculture (pp. 257-278). InTech. doi: 10.5772/926.

Mclvor, IR, Sloan, S, \& Rovira Pigem, L. (2013). Genetic and environmental influences on root development in cuttings of selected Salix and Populus clones - a greenhouse experiment. Plant Soil, 377, 25-42. doi: 10.1007/ s11104-013-1770-5.

National Poplar and Willow Users Group. (2007). Growing Poplar and Willow Trees on Farms Guidelines for Establishing and Managing Poplar and Willow Trees on Farms. Compiled and Prepared by the National Poplar and Willow Users Group as part of the Sustainable Farming Fund's Poplar \& Willow Project (Grant No. 04/089). http://www.poplarandwillow.org.nz/files/growing-poplar-and-willowtrees-on-farms.pdf Accessed March 2014.

O'Loughlin, C, Marden, M, Fantham, P, Shrivastava, A, \& (compilers). (2008). Workshop Report Poplar and willow planting on land Overlay 3A Gisborne, East Coast region, jointly organised by the Ministry of Agriculture and Forestry and Gisborne District Council. Wellington, New Zealand: Ministry of Agriculture and Forestry.

Pacaldo, RS, Volk, TA, \& Briggs, RD. (2013). Greenhouse gas potentials of shrub willow biomass crops based on below- and aboveground biomass inventory along a 19-year chronosequence. Bioenergy Research, 6(1), 252-262.

Pallardy, SG, Gibbins, DE, \& Rhoads, JL. (2003). Biomass production by two-yearold poplar clones on floodplain sites in the Lower Midwest, USA. Agroforestry Systems, 59, 21-26.

Phillips, C, \& Marden, M. (2005). Reforestation schemes to manage regional landslide risk. In T Glade, MG Anderson, \& MJ Crozier (Eds.), Landslide hazard and risk (pp. 731-752). Chichester: John Wiley.

Phillips, CJ, Marden, M, \& Pearce, AJ. (1991). Effectiveness of reforestation in prevention and control of landsliding during large cyclonic storms. In Proc 19th Int Union For Res Org, Montreal (pp. 358-361).
Phillips, CJ, Ekanayake, JC, \& Marden, M. (2011). Root site occupancy modelling of young New Zealand native plants: implications for soil reinforcement. Plant Soil, 346, 201-214. doi: 10.1007/s11104-011-0810-2.

Puri, S, \& Thompson, FB. (2003). Effect of soil and plant water relations on rooting of Populus $x$ euramericana stem cuttings. New Forests, 25(2), 109-124.

Rosser, BJ, \& Ross, CW. (2011). Recovery of pasture production and soil properties on soil slip scars in erodible siltstone hill country, Wairarapa, New Zealand. New Zealand Journal of Agricultural Research, 54, 23-44.

Sands, R, \& Bowen, GD. (1978). Compaction of sandy soils in radiata pine forests. II. Effects of compaction on root configuration and growth of radiata pine seedlings. Australian Forest Research, 8, 163-170.

Stokes, A, Atger, C, Bengough, AG, Fourcaud, T, \& Sidle, RC. (2009). Desirable plant root traits for protecting natural and engineered slopes against landslides. Plant Soil, 324, 1-30. doi: 10.1007/s11104-009-0159-y.

Sulaiman, Z. (2006). Establishment and silvopastoral aspects of willow and poplar (PhD thesis). Palmerston North, New Zealand: Massey University.

Thompson, RC, \& Luckman, PG. (1993). Performance of biological erosion control in New Zealand soft rock hill terrain. Agroforestry Systems, 21, 191-211.

van Kraayenoord, CWS, \& Hathaway, RL (Eds.). (1986). Plant materials handbook for soil conservation, Vol 2: Introduced plants. Water and Soil Misc Publ 94. Wellington, New Zealand: National Water and Soil Conservation Authority.

Van Kraayenoord, CWS, Slui, B, \& Knowles, FB. (1995). Introduced forest trees in New Zealand: Recognition, role and seed source: The willows Salix spp. (FRI Bulletin No. 124, part 15). Rotorua, New Zealand: New Zealand Forest Research Institute.

Watson, A, \& O'Loughlin, C. (1990). Structural root morphology and biomass of three age classes of Pinus radiata. New Zealand Journal of Forestry Science, 20, 97-110.

Watson, A, Phillips, C, \& Marden, M. (1999). Root strength, growth, and rates of decay: root reinforcement changes of two tree species and their contribution to slope stability. Plant and Soil, 217, 39-47.

Watt, M, Silk, WK, \& Passioura, JB. (2006). Rates of root and organism growth, soil conditions, and temporal and spatial development of the rhizosphere. Annals of Botany, 97(5), 839-855.

Wilkinson, AG. (1999). Poplars and willows for soil erosion control in New Zealand. Biomass Energy, 16, 263-274.

Zacchini, M, Pietrini, F, Mugnozza, G, lori, V, Pietrosanti, L, \& Massacci, A. (2009). Metal tolerance, accumulation and translocation in poplar and willow clones treated with cadmium in hydroponics. Water Air Soil Pollution, 197, 23-34.

Zalesny, RS, \& Zalesny, JA. (2011). Clonal variation in lateral and basal rooting of populus irrigated with landfill leachate. Silvae Genetica, 60(1), 35-44.

Zhang, X, Phillips, C, \& Marden, M. (1993). A comparison of earthflow movement mechanisms on forested and grassed slopes, Raukumara Peninsula, North Island, New Zealand. Geomorphology, 6, 175-187.

\section{doi:10.1186/s40490-014-0015-6}

Cite this article as: Phillips et al:: Observations of root growth of young poplar and willow planting types. New Zealand Journal of Forestry Science $201444: 15$

\section{Submit your manuscript to a SpringerOpen ${ }^{\odot}$ journal and benefit from:}

- Convenient online submission

- Rigorous peer review

- Immediate publication on acceptance

- Open access: articles freely available online

- High visibility within the field

- Retaining the copyright to your article

Submit your next manuscript at springeropen.com 